\title{
P. R. S. Moorey, MA, DPhil, FBA, FSA (1937-2004)
}

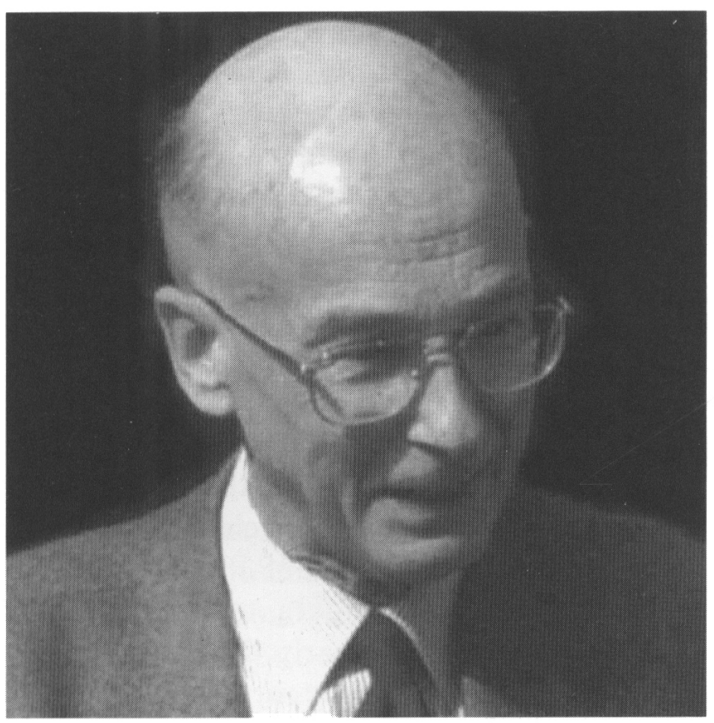

Roger Moorey, formerly Keeper of Antiquities at the Ashmolean Museum, Oxford and widely regarded as the leading scholar of Near Eastern archaeology of his generation, died on 23 December 2004 at the age of 67 . Following an era of discovery and research dominated by the excavators of the major sites, he brought an intellectual nimbleness and breadth of scholarship that set new benchmarks of balance, rigour and interpretive sophistication. His range and depth of knowledge were legendary. In a career based entirely in the Ashmolean Museum, he made seminal contributions to the understanding of many aspects of ancient material culture across the Near East: from Egypt and the Levant through Syria and Mesopotamia to Iran, and from the prehistoric to Achaemenian periods. The cogency, integrity and graciousness of his scholarship (one looks in vain for a mean-spirited put-down) were reflections of a mind that compromised none of its incisiveness for being, as he once said, "appreciative rather than critical"; and his natural collegiality cut across the divides of contemporary Middle Eastern politics. At once a specialist in many things and a generalist of rare breadth and insight, he was for a generation of colleagues and students an inspiring example of the "compleat scholar".

Although his excavation experience was limited, Moorey's approach to understanding ancient cultures was always founded very firmly on direct scrutiny of the material remains, supplemented by innovative use of scientific analysis and close attention to the historical and other textual evidence. He was not inclined to abstract theorizing but read widely and was sensitive to new methodologies without being captive to intellectual fashion. His publications (some seventeen books, over ninety articles and seventy reviews) ranged from excavation reports and catalogues of particular corpora to broad synthetic studies, as well as some of the clearest and most useful works of popularization. ${ }^{1}$ Much of his work quickly acquired the status of standard references and established new starting points for future research. For those of us based in Oxford, his regular presence in the Griffith Institute library was an object lesson in the commitment and focus that lies behind scholarship at the highest level. And for Near Eastern scholars who came to Oxford from around the world, his hospitality and generosity with his time and knowledge were a constant source of astonishment.

\footnotetext{
${ }^{1}$ See the bibliography of major publications to 2002 (with some inadvertent omissions) in T. Potts, M. Roaf and D. Stein (eds.), (ulture through Objects: Ancient Near Eastern Studies in Honour of P. R. S. Moorey, Griffith Institute, Oxford, 2003, 11-16. His most significant subsequent
}

publications are Idols of the People, Miniature Images of Clay in the Ancient Near East, Schweich Lectures 2001, Oxford 2003; and Ancient Near Eastern Terracottas, with a catalogue of the collection in the Ashmolean Museum, Oxford Oxford 2005 (and on-line) 
Peter Roger Stuart Moorey was born in Bush Hill Park, Middlesex on 30 May 1937. Losing both parents at a young age, he was sent to Mill Hill School as a boarder, followed by National Service in Cyprus, 1956-8 - his first encounter with the broader Near East - as a member of the Intelligence Corps (an episode he was always quick to qualify: "intelligence is what we did, not what we had"). In 1958 he went up to Corpus Christi College, Oxford as an Exhibitioner. A brilliant student, he took a First in Modern History and was invited to sit for a Prize Fellowship at All Souls, joining the distinguished list of runners-up. His interest in archaeology and the ancient Near East had been kindled already in his schooldays, and developed further in Cyprus and then Oxford through active involvement with the university's Archaeological Society. Soon after graduating in 1961 he was appointed to an Assistant Keepership at the Ashmolean Museum; it was, as he realized, the opportunity of a lifetime and he never looked back. The Keeper of Antiquities at Ashmolean was then R. W. Hamilton, who became a mentor to the young Moorey and advised him to acquire a broad knowledge of the Near East rather than specialising in one area. This suited Moorey's wide-ranging curiosity ("everything from Ur to Samarra", as he put it) and helped him thrive in a position that ranged over the entire Near East including Egypt and, later, Cyprus. Concurrently with his museum duties, he chose to undertake a doctorate, supervised by Max Mallowan, on the Ashmolean's collection of Persian bronzes - to the dismay (as he recalled with amusement) of many Oxford colleagues, to whom higher degrees were a stratagem of last resort. It set a pattern of working on clearly defined projects to rigorous, self-imposed deadlines that sustained him through the rest of his career.

In 1973 Moorey became Senior Assistant Keeper of Antiquities and in 1983 the Keeper, the position from which he retired in June 2002. Although he never aspired to higher administrative positions, always choosing scholarship over status, his broad intellectual vision, sound judgement and consensual diplomacy made him much sought-after on committees, and the obvious choice as the Ashmolean's acting director when duty called. He was appointed a Governing Body Fellow of Wolfson College in 1976 and played an active role in college life up to the end, most recently as Senior Research Fellow and Vicegerent (2002-4). His appointment to Wolfson seems to have been precipitated when its President, Isaiah Berlin, discovered that Moorey's imminent election to a Fellowship of the British Academy - at the young age of forty - would make him the only such distinguished Oxford scholar without a college affiliation. Within the Academy he was appointed Chairman of the Archaeology Section from 1987-91 and a member of the Standing Committee on Overseas Schools and Institutes from 1987-96. His direct involvement with the Schools was extensive: he served for over a quarter century on the Executive Committee and Council of the BSAI (1970-96), and was a member of the Committees of the British Institute of Persian Studies (1972-94), the Amman Institute (Vice-Chairman 1988-92), and, most significantly, the Jerusalem School, where he was founding editor of Levant (1968-86), Chairman of the Publications Committee (from 1987) and President (1991-9). A committed teacher, he supervised many doctoral students from 1972 (Michael Roaf) until his retirement and was a major voice in the introduction of the first Oxford undergraduate degree in Archaeology and Anthropology in 1993, for which he took on a substantial teaching load. (Though he admitted to holding the "oldfashioned Oxford view" that archaeology is best approached with a solid grounding in history and languages, he saw that this was the way of the future and embraced it.)

Mesopotamia lay at the centre of Moorey's interests both geographically and intellectually, connecting east and west with his two other abiding preoccupations: Iran and the Levant. ${ }^{2}$ It was also the subject of his first publication in 1964 (on the plano-convex building at Kish) - and the first of some fifteen studies to appear in this journal. Though not himself a dirt archaeologist, Moorey worked extensively (and selflessly) to resuscitate other people's excavations, publishing detailed reports on the Langdon/Watelin expedition to Kish ("to acquit, as far as is now possible, an obligation laid on Oxford University in 1923") (1978), and on the Lawrence/Woolley excavations at Deve Hüyük (1980). In 1969 sabbatical research on Kish took him for the first time to

\footnotetext{
${ }^{2}$ This review focuses on his Mesopotamian contribution. For a longer personal appreciation, with more detail on his work on the Levant, see the obituaries by C. Dauphin in
}

Bulletin of the Anglo-Israel Archaeological Society 22 (2004), 86-96 and Palestine Exploration Quarterly in press, upon which I have drawn here. 
Iraq and Iran. He returned to Iraq for three seasons (1975, 1977 and 1981) as registrar on Nicholas Postgate's excavations at Abu Salabikh, his only Mesopotamian fieldwork.

Moorey took very seriously the obligation of those in museums to make their collections, and the knowledge derived from archaeology generally, accessible to a non-specialist public. In addition to writing introductory museum guides on biblical archaeology, Egypt, the Luristan bronzes, Iran, Iraq and the Near East, he also produced updated editions of the most successful archaeological popularizations of the past: Woolley's Ur "of the Chaldees" (1982) and Kenyon's The Bible and Recent Archaeology (1987), no doubt inspired in both cases by his admiration for their authors' dual talent as excavator and popularizer. As a schoolboy Moorey had heard Woolley lecture and greatly respected his rigorous publication record. He came under Kenyon's influence at Oxford, where she was Principal of St Hugh's College, and in 1963 had his first Near Eastern excavation experience as one of her site-supervisors on the Ophel ridge in Jerusalem. His own popular books, especially those dealing with the biblical world $(1975,1981,1991)$, were translated into many languages, and remain among the most masterful marriages of fine scholarship and clear, engaging prose in print.

Moorey worked steadily over four decades on a number of catalogues of material from the Ashmolean (plus, occasionally, other museums and private collections associated with Oxford) setting an exemplary model of responsible publication. Studies of the Ashmolean's Persian bronzes (his revised DPhil thesis, 1971) and terracotta figurines (2005) formed the bookends of his career, with catalogues of stamp seals, cylinder seals (both with B. Buchanan) and Canaanite bronze statuettes in between.

He took a special interest in metalwork, faience and related vitreous technologies from cultures across the Near East, supplementing traditional typological and iconographical study with newly developed technical and material analyses, on which he collaborated with colleagues at the Oxford Research Laboratory for Archaeology and the History of Art. This gave rise to important insights into industrial practices, the identification of workshops and styles, and patterns of trade. The Mesopotamian evidence was brought together in his 1985 study on Materials and Manufacture in Ancient Mesopotamia, the Evidence of Archaeology and Art: Metals and Metalwork, Glazed Materials and Glass. This was later expanded into a comprehensive analysis of all the principal surviving materials and technologies in Ancient Mesopotamian Materials and Industries: The Archaeological Evidence (1994/1999). Immediately recognized as a landmark publication, this constitutes Moorey's magnum opus. One can say with confidence that no one else could so successfully have marshalled and synthesized such a large body of archaeological, art historical, philological and scientific evidence.

Moorey's many other Mesopotamian papers range over topics of iconography and typology on specific objects/categories (metalwork, faience, stonework, sculpture, terracottas), sourceprovenance analyses (metals, stones), the history of crafts and technologies, the reconstruction of grave groups and stratigraphy, as well as numerous culture-historical problems that attracted his curiosity: the function of third-millennium buildings at Kish and Jemdet Nasr; the occupants of the "Royal Tombs" of Ur; the burial site of the Ur III kings; early Sumerian/Elamite-Egyptian relations; the origins of horse-riding, chariots and warfare; Hurrian/Mittanian technological innovations; the comparative chronology of the mid-third millennium; early Iranian historical geography; and so on.

In all his writings Moorey's methodology was thoroughly empirical, scrutinizing the evidence object by object and keeping generalization within prudent bounds. But his interpretive intelligence was at the same time highly synthetic and interdisciplinary, seeing patterns and relationships, connections and discontinuities that had escaped others. He was deeply reflective about the nature of archaeological thinking (he especially admired R. G. Collingwood, the only archaeologistphilosopher), appreciating how our own cultural and intellectual environment affects the assumptions and prejudices we bring to our work. This informed his keen interest in the modern historiography of the Near East. His writings often include masterful summaries of previous research, which reached the level of true intellectual history in A Century of Biblical Archaeology (1992). It is a cause for deep regret that we will learn no more from him in this vein. Moorey's early career corresponded with the emergence of the "new archaeology", when many saw the 
brightest prospects for future research in new theoretical frameworks. Where Moorey was convinced that these made sense of the material and could be tested against the primary evidence he utilized them; where he did not, he relied upon his wide reading in history, anthropology, sociology and other neighbouring disciplines to give human form to the fragmentary material evidence to help him (as he once quoted Woolley) "through the dead-and-gone things, to get at the history and minds of dead-and-gone men" (unpublished lecture on Hogarth, Lawrence and Woolley, Ashmolean Museum, 10 June 1983). It is a measure of his success in this that Moorey's work continues to be used and admired by Near Eastern scholars of all methodological complexions.

His extraordinary contributions were acknowledged in prizes and awards for both Mesopotamian and Levantine archaeology, fields in which few if any contemporaries (or predecessors) could claim equal grounding: the Schimmel Prize of the Israel Museum for contributions to the archaeology of Eretz Israel and the Lands of the Bible (1989); the "best popular book" award of the Biblical Archaeology Society for A Century of Biblical Archaeology (1993); and the James R. Wiseman Book Award of the Archaeological Institute of America for Ancient Mesopotamian Materials and Industries (1996). In 2001 he was invited to deliver the British Academy's Schweich Lectures on Biblical Archaeology, choosing as his topic "Idols of the People: Miniature Images of Clay in the Ancient Near East" (2003). In March 2003 he was the fourth recipient of the BSAI's Gertrude Bell Medal, in recognition of his outstanding contributions to Mesopotamian archaeology. This was also the year of his Festschrift, Culture through Objects, which had to be prepared surreptitiously for fear of invoking his diffident disapproval. In the end he received it at the London Rencontre with characteristic graciousness and apparent pleasure.

Roger Moorey lived alone and remained a bachelor throughout his life, but derived much support and pleasure from his family - a sister, half-sister (both younger) and step-mother. To his "professional family" in Near Eastern archaeology the untimely death of so fine a scholar, on the brink of a retirement full of promise (he had begun a book on ancient warfare), is cause for great sadness. But it is as a friend of such uncommon humanity, kindness and gentle wisdom that his passing is most keenly felt.

Timothy Potts 